\title{
PRODUCTIVITY AND SEED HEALTH OF HUSKED OATS (Avena sativa L.) GROWN UNDER DIFFERENT SOIL MOISTURE CONDITIONS
}

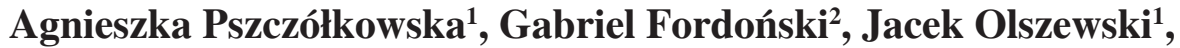 \\ Tomasz Kulik ${ }^{1}$, Iwona Konopka ${ }^{2}$
}

\author{
${ }^{1}$ Department of Diagnostics and Plant Pathophysiology, Plac Łódzki 5, 10 -727 Olsztyn, Poland \\ ${ }^{2}$ Department of Processing and Chemistry of Plant Raw Materials, Plac Cieszyński 1, 10-726 Olsztyn, Poland \\ University of Warmia and Mazury \\ e-mail: agnieszka.pszczolkowska@uwm.edu.pl
}

Received: 15.06 .2010

\section{Abstract}

The present study investigated the effect of different soil moisture content levels $(60-70 \%$ SWC (soil water capacity) - control; $30-35 \%$ SWC - water stress) on yields, gas exchange parameters, seed health, and protein fractions of husked oat grain. The study showed that water deficit resulted in a decrease in grain weight per plant and a reduction in the gas exchange rates, primarily the photosynthesis and transpiration rates. Cladosporium cladosporioides was the dominant species on oat kernels in both experimental treatment options and in both years of the study. The presence of Fusarium poae was also found. Higher contents of prolamin, albumin and globulin fractions were found in the oat grain harvested from plants grown under soil water deficit conditions.

Key words: oats, yield, gas exchange rates, seed health, protein fractions

\section{INTRODUCTION}

Oat is a cereal grain of high dietary value. In its composition, it contains large amounts of good quality protein, fat rich in unsaturated fatty acids, dietary fibre rich in water-soluble $\beta$-glucans, tocols, phenolic compounds with antioxidant properties, and many other substances that may have a beneficial effect on the functioning of the organism (B a r t n i k ow ska et al. 2002B). The high nutritional value of protein in oat grain has been used to develop the production technology for protein concentrates and isolates as additives in the manufacture of meat and bakery products (Bartnikowska et al. 2000A). This is why human nutrition experts have suggested for many years that the proportion of the so-called non-bread cereals should be increased in daily dietary intake, particularly oats and barley ( $\mathrm{G}$ ą s i o r o w s k i and $\mathrm{K}$ a w k a, 1995).

Grain for human consumption should be characterized by high quality and be free from fungal pathogens which may produce mycotoxins dangerous to humans and animals. The species of the genus Fusarium have a major role here, since in cereal grains they most frequently produce trichothecenes from the group of sesquiterpenoids ( $\mathrm{Nich} \mathrm{ols} \mathrm{on} \mathrm{et} \mathrm{al.} \mathrm{2003;}$ $\mathrm{Nichols}$ on et al. 2004).

Grain yield and quality are dependent on both habitat conditions and agricultural practices (Wróbel and Kijora, 2004). Oats are generally considered to be plants with low thermal requirements and high water requirements, mainly during the period from stem elongation to panicle emergence ( $\mathrm{P}$ a n e k , 1992).

Water deficit is one of the principal factors that reduce crop productivity (Grzesiuk et al. 1999; $\mathrm{S} \mathrm{t} \mathrm{a} \mathrm{r} \mathrm{c} \mathrm{k} \mathrm{et} \mathrm{al.} \mathrm{1995).} \mathrm{Plants} \mathrm{respond} \mathrm{differently} \mathrm{to} \mathrm{wa-}$ ter deficiency in different periods of their growth. The generative phase and the beginning of flowering are most frequently the period of the greatest sensitivity to water deficit (Grze si u k et al. 1999, S k rabka 1992). Furthermore, water deficit leads to the disturbance of the basic physiological processes, chiefly photosynthesis. On the one hand, this is caused by limited access of $\mathrm{CO}_{2}$ from the outside air as a result of the decreased permeability of stomata and, on the other hand, by the reduced activity of the enzymes participating in photosynthesis ( $\mathrm{S} \mathrm{k} \mathrm{ra} \mathrm{b} \mathrm{k} \mathrm{a,} \mathrm{1992).}$

If oat grain is intended for human consumption, not only its health is of essential significance, but also its technological value, in particular the composition of proteins. In quantitative terms, globulins make up the 
largest percentage of proteins in oat kernels, from 50 to $80 \%$, while prolamin and glutelin fractions account for the remaining part (more than $20 \%$ of total protein) (Gąsiorowski, 1995; Bartnikowska et al. 2000A). But there is no gluten in oat kernels, which excludes oat grain as raw material used for bread baking ( $\mathrm{S} \mathrm{u} \mathrm{e}$ k et al. 2005). In connection with the above, oat grain may and should be used in the diet of people suffering from coeliac disease.

The aim of the present study was to determine plant productivity, seed health, and protein fractions of oats grown under different soil moisture conditions.

\section{MATERIALS AND METHODS}

In the period 2004-2005, a single-factor pot experiment was carried out in two experimental series, in quadruplicate, in a greenhouse of the University of Warmia and Mazury in Olsztyn. The experimental factor was varying soil moisture content: $60-70 \%$ SWC (soil water capacity) - control; 30 - 35\% SWC - water stress; such conditions were maintained from the stage with $50 \%$ of panicle emerged (BBCH 55) to the milk stage of grain development (BBCH 75). Oats were grown in Kick-Brauckmann pots. Before sowing, the pots were filled with typical brown soil with the following nutrient availability: $\mathrm{P}_{2} \mathrm{O}_{5}-6.41 \mathrm{mg} \times \mathrm{kg}^{-1}$ of soil, $\mathrm{K}_{2} \mathrm{O}-1.30 \mathrm{mg} \times \mathrm{kg}^{-1}, \mathrm{Mg}-190 \mathrm{mg} \times \mathrm{kg}^{-1}$, and $\mathrm{pH}$ in $1 \mathrm{~N} \mathrm{KCl}-6.78$. In the present study, seeds of husked oats (Avena sativa L.) cv. Flämingsstern were used; before sowing they were treated with a fungicide seed dressing, Funaben T. Sowing was done on 30 April and 5 May, respectively, in the study years. 12 seeds were sown in each pot and after emergence 8 plants per pot were left. During the growing process, the plants were fed with Hoagland's medium. The plants were watered with distilled water 2-3 times per day, and soil moisture content was monitored using a soil moisture meter, in accordance with the methodological assumptions. During the growing period, average daily temperature ranged from 18 to $22^{\circ} \mathrm{C}$, whereas the day length was adjusted to natural light conditions facilitating the growth of oats. Chemical protection against fungal pathogens was also used by applying the fungicide Amistar 250SC at the flag leaf stage flag leaf fully unrolled (BBCH 39-41), and the pesticide Nurelle 550EC against oat pests (twice) at the heading stage (BBCH 52) and at the end of flowering (BBCH 69).

During the investigations, the gas exchange rates were determined using a LI-COR 6400 portable photosynthesis system. The determinations were performed at a constant $\mathrm{CO}_{2}$ concentration of $400 \mathrm{ppm}$ and a light intensity of $1000 \mu \mathrm{mol} \mathrm{m} \mathrm{m}^{-2} \times \mathrm{s}^{-1}$. The source of photons was a LED light source emitting light with the main peak wavelength of $670 \mathrm{~nm}$ and the lower peak wavelength of $465 \mathrm{~nm}$. The measurements were made three times (at the following stages: panicle emergence, full flowering, grain formation) on the flag leaf. Each measurement was repeated ten times.

A phytopathological analysis was performed to estimate fungal colonization of the grain. In order to evaluate seed health using the traditional method, 100 seed samples were randomly selected; kernels were surface sterilized with $70 \%$ ethanol, $1 \%$ sodium hypochlorite and finally washed three times in sterile distilled water. The material so prepared was plated on Petri dishes with solid PDA medium. The dishes with the seeds were stored in a laboratory oven at a temperature of $20-23^{\circ} \mathrm{C}$ for $7-10$ days, and subsequently the grown fungal cultures were identified to fungal genus and species based on the morphological features under an optical microscope, using the available monographic studies of Ell is (1971), Gilman (1957), and Kw a śn a et al. (1991).

Grain weight per plant, 1000 grain weight (TGW), and some biometric features of the plants were determined (plant height, number of panicles per plant, number of grains per panicle).

To determine the content of particular protein fractions, a $3 \mathrm{~g}$ grain sample was ground in an IKA A10 laboratory mill (Labortechnik) in such a manner so that all particles could be sieved through a $400 \mu \mathrm{m}$ mesh sieve (ether particles smaller than $250 \mu \mathrm{m}$ accounted for $90 \%$ ). The samples were degreased with petroleum ether in Soxhlet extractors (16 hours). After evaporation of the solvent, $100 \mathrm{mg}$ portions of powder were weighed out and placed in Eppendorf tubes, and then three protein fractions were extracted according to Wieser et al. (1998).

1) albumins + globulins - triple extraction of $1 \mathrm{~cm}^{3}$ of the mixture $\left(0.4 \mathrm{~mol} \times \mathrm{L}^{-1} \mathrm{NaCl}+0.067 \mathrm{~mol} / \mathrm{L}\right.$ $\mathrm{HKNaPO}_{4}$ with a pH of 7.6

2) prolamins - triple extraction of $1 \mathrm{~cm}^{3}$ of the mixture $(60 \%$ ethanol)

3) glutelins - double extraction of $1 \mathrm{~cm}^{3}$ of the mixture $\left(50 \% \mathrm{propanol}^{-1}+2 \mathrm{~mol} / \mathrm{L}\right.$ urea $0.05 \mathrm{~mol} \times \mathrm{L}^{-1}$ Tris $\mathrm{HCl}(\mathrm{pH} 7.5)+1 \%$ DTE under nitrogen.

The first two protein fractions were extracted at room temperature using an Eppendorf thermomixer (10-minute extraction). Glutelins were extracted at a temperature of $60^{\circ} \mathrm{C}$ in the thermomixer. After each extraction, the mixture was centrifuged at $11000 \mathrm{x} \mathrm{g}$. The collected fractions were lyophilized and then dissolved in $2 \mathrm{~cm}^{3}$ of the respective phase (1-3), cleaned through a Spartan - 3NY filter with a $0.45 \mu \mathrm{m}$ mesh and transferred to glass vials. The determinations were made using a Hewlett Packard Series 1050 system with the following parameters: column RP-18 Vydac 218TPP54, $5 \mu \mathrm{m}, 250 \times 4.6 \mathrm{~mm}$, pre-column Zorbax 
3000SB-C18 4.6x $12.5 \mathrm{~mm}$, column temperature $45^{\circ} \mathrm{C}$, mobile phase flow rate $1 \mathrm{ml} \times$ min, injection size $20 \mu \mathrm{l}$. The separation was performed using a two-component gradient. The proportion of component A: $0 \min 75 \%$, $5 \min 65 \%, 10 \min 50 \%, 17 \min 25 \%, 18 \min 15 \%$, 19 min $75 \%$. The first gradient (A) was water with an addition of $0.1 \%$ TFA, while the second gradient (B) was ACN with an addition of $0.1 \%$ TFA. The detection was carried out using a detector manufactured by the same company, and the reading was done at a wavelength of $210 \mathrm{~nm}$.

The results were analysed using HPLC 3D Chem Station software (Hewlett Packard).

The assays of protein fractions were carried out at the Department of Processing and Chemistry of Plant Raw Materials, Faculty of Food Sciences, University of Warmia and Mazury in Olsztyn.

Statistical calculations were performed using the STATISTICA software package (data analysis software system, version 6, StatSoft, Inc. 2003) based on the analysis of variance. Differences between means were determined at a significance level of $p=0.01$. The mean values for grain weight per plant, biometric features, rates of photosynthesis and transpiration, intercellular-space $\mathrm{CO}_{2}$ concentration, and stomatal conductance were classified into homogeneous groups using Fisher's test of significance.

\section{RESULTS AND DISCUSSION}

The present study showed that a reduction in soil moisture content from $60-70 \%$ SWC down to $30-35 \%$ SWC starting from the stage with $50 \%$ of panicle emerged up to the milk stage of grain development resulted in a decrease in grain weight per plant (Table 1). Podolska as well as HołubowiczK liza (2006A and 2006B) also demonstrated that cereal plants were characterized by the greatest sensitivity to water deficit during the heading, flowering and grain development stages.

Table 1

Some biometric features of oats cv. Flämingsstern under different soil moisture conditions (means for 2004 - 2005)

\begin{tabular}{ccccccc}
\hline Cultivar & $\begin{array}{c}\text { Soil water } \\
\text { capacity } \\
(\%)\end{array}$ & $\begin{array}{c}\text { Plant height } \\
(\mathrm{cm})\end{array}$ & $\begin{array}{c}\text { Number of panicles } \\
\text { per plant }\end{array}$ & $\begin{array}{c}\text { Number of } \\
\text { grains per } \\
\text { panicle }\end{array}$ & $\begin{array}{c}\text { Thousand grain } \\
\text { weight }(\mathrm{g})\end{array}$ & $\begin{array}{c}\text { Grain weight } \\
\text { per plant }(\mathrm{g})\end{array}$ \\
\hline \multirow{2}{*}{ Flämingsstern } & $60-70 \%$ & $57.05 \mathrm{a}$ & $5.21 \mathrm{~b}$ & $24.31 \mathrm{a}$ & $23.98 \mathrm{a}$ & $2.57 \mathrm{~b}$ \\
\cline { 2 - 7 } & $30-35 \%$ & $58.68 \mathrm{a}$ & $2.70 \mathrm{a}$ & $21.96 \mathrm{a}$ & $20.45 \mathrm{a}$ & $1.09 \mathrm{a}$ \\
\hline
\end{tabular}

Homogeneous groups a, ab, b, according Fisher's LSD test

Table 2

Gas exchange rates for oats under different soil moisture conditions in 2004

\begin{tabular}{|c|c|c|c|c|c|c|c|c|c|c|c|c|c|}
\hline \multirow{3}{*}{ Cultivar } & \multirow{3}{*}{$\begin{array}{c}\text { Soil } \\
\text { water } \\
\text { capacity } \\
(\%)\end{array}$} & \multicolumn{3}{|c|}{ Photosynthesis } & \multicolumn{3}{|c|}{ Transpiration } & \multicolumn{3}{|c|}{$\begin{array}{c}\text { Intercellular-space } \mathrm{CO}_{2} \\
\text { concentration }\end{array}$} & \multicolumn{3}{|c|}{ Stomatal conductance } \\
\hline & & \multicolumn{3}{|c|}{$\left(\mu \mathrm{molCO}{ }_{2} \mathrm{~m}^{-2} \mathrm{~s}^{-1}\right)$} & \multicolumn{3}{|c|}{$\left(\mathrm{mmolH}_{2} \mathrm{Om}^{-2} \mathrm{~s}^{-1}\right)$} & \multicolumn{3}{|c|}{$\left(\mu \mathrm{molCO}{ }_{2} \mathrm{~mol}^{-1}\right)$} & \multicolumn{3}{|c|}{$\left(\mathrm{molH}_{2} \mathrm{Om}^{-2} \mathrm{~s}^{-1}\right)$} \\
\hline & & I & II & III & I & II & III & I & II & III & I & II & III \\
\hline \multirow{2}{*}{ Flämingsstern } & $60-70 \%$ & $13.7 \mathrm{~b}$ & $12.6 b$ & $13.8 \mathrm{~b}$ & $4.5 b$ & $3.5 b$ & $5.2 \mathrm{~b}$ & $321 b$ & $312 b$ & $327 \mathrm{ab}$ & $0.52 b$ & $0.40 \mathrm{~b}$ & $0.57 b$ \\
\hline & $30-35 \%$ & $4.4 \mathrm{a}$ & $5.0 \mathrm{a}$ & $4.2 \mathrm{a}$ & $1.2 \mathrm{a}$ & $0.9 \mathrm{a}$ & $1.6 \mathrm{a}$ & $266 \mathrm{a}$ & $239 a$ & $264 a$ & $0.07 \mathrm{a}$ & $0.06 \mathrm{a}$ & $0.10 \mathrm{a}$ \\
\hline
\end{tabular}

I - Measurement of gas exchange rates at panicle emergence; II - Measurement of gas exchange rates at full flowering III - Measurement of gas exchange rates at grain formation Homogeneous groups a, ab, b, according Fisher's LSD test 
Table 3

Gas exchange rates for oats under different soil moisture conditions in 2005

\begin{tabular}{|c|c|c|c|c|c|c|c|c|c|c|c|c|c|}
\hline \multirow{3}{*}{ Cultivar } & \multirow{3}{*}{$\begin{array}{c}\text { Soil water } \\
\text { capacity } \\
(\%)\end{array}$} & \multicolumn{3}{|c|}{ Photosynthesis } & \multicolumn{3}{|c|}{ Transpiration } & \multicolumn{3}{|c|}{$\begin{array}{l}\text { Intercellular-space } \mathrm{CO}_{2} \\
\text { concentration }\end{array}$} & \multicolumn{3}{|c|}{ Stomatal conductance } \\
\hline & & \multicolumn{3}{|c|}{$\left(\mu \mathrm{molCO}{ }_{2} \mathrm{~m}^{-2} \mathrm{~s}^{-1}\right)$} & \multicolumn{3}{|c|}{$\left(\mathrm{mmolH}_{2} \mathrm{Om}^{-2} \mathrm{~s}^{-1}\right)$} & \multicolumn{3}{|c|}{$\left(\mu \mathrm{molCO}_{2} \mathrm{~mol}^{-1}\right)$} & \multicolumn{3}{|c|}{$\left(\mathrm{molH}_{2} \mathrm{Om}^{-2} \mathrm{~s}^{-1}\right)$} \\
\hline & & I & II & III & I & II & III & I & II & III & I & II & III \\
\hline \multirow{2}{*}{ Flämingsstern } & $60-70 \%$ & $16.9 \mathrm{a}$ & $15.2 b$ & $15.0 \mathrm{~b}$ & $3.9 \mathrm{~b}$ & $3.6 b$ & $3.2 b$ & $295 b$ & $177 \mathrm{ab}$ & $141 \mathrm{a}$ & $0.33 b$ & $0.05 \mathrm{a}$ & $0.22 b$ \\
\hline & $30-35 \%$ & $12.7 \mathrm{a}$ & $6.2 \mathrm{a}$ & $7.2 \mathrm{a}$ & $2.6 \mathrm{a}$ & $1.5 \mathrm{a}$ & $0.8 \mathrm{a}$ & $223 a$ & $130 \mathrm{a}$ & $114 a$ & $0.09 a$ & $0.02 \mathrm{a}$ & $0.03 \mathrm{a}$ \\
\hline
\end{tabular}

I - Measurement of gas exchange rates at panicle emergence; II - Measurement of gas exchange rates at full flowering III - Measurement of gas exchange rates at grain formation Homogeneous groups a, ab, b, according Fisher's LSD test

Table 4

Number of fungal isolates in the grain of oats cv. Flämingsstern under different soil moisture conditions in 2004

\begin{tabular}{lcc}
\hline \multicolumn{1}{c}{ Fungal species } & Control & Water stress \\
\cline { 2 - 3 } & $60-70 \%$ soil water capacity & $30-35 \%$ soil water capacity \\
\hline 1. Acremoniella atra (Corda) Sacc. & - & 4 \\
2. Alternaria alternata Keissler Nees & 3 & 6 \\
3. Cladosporium cladosporioides (Fr.) de Wries & 36 & 25 \\
4. Fusarium poae (Peck) Wollenw. & 15 & 6 \\
5. Penicillium spp. & 12 & 3 \\
6. Sclerotinia sclerotiorum (Lib.) de Bary & 1 & - \\
7. Stemphylium botryosum Wallroth & - & 1 \\
8. Yeast-like mycelia & - & 4 \\
\hline Total & 67 & 49 \\
\hline
\end{tabular}

SWC - soil water capacity; $60-70 \%$ SWC - control; 30 - 35\% SWC - water stress

Table 5

Number of fungal isolates in the grain of oats cv. Flämingsstern under different soil moisture conditions in 2005

\begin{tabular}{lcc}
\hline \multicolumn{1}{c}{ Fungal species } & Control & Water stress \\
\cline { 2 - 3 } & $60-70 \%$ soil water capacity & $30-35 \%$ soil water capacity \\
\hline 1. Alternaria alternata Keissler Nees & 1 & 2 \\
2. Cladosporium cladosporioides (Fr.) de Wries & 8 & 4 \\
4. Fusarium poae (Peck) Wollenw. & 1 & 3 \\
5. Mucor spp. & - & 1 \\
5. Papularia sphaerospherma & - & 1 \\
6. Penicillium spp. & 11 & 4 \\
\hline
\end{tabular}

SWC - soil water capacity; 60 - 70\% SWC - control; 30 - 35\% SWC - water stress 
Table 6

Protein fraction content in the grain of oats cv. Flämingsstern under different soil moisture conditions (the peak area calculated as $\mathrm{mAU} \times \mathrm{s}$ )

\begin{tabular}{lccc}
\hline Soil water capacity (\%) & albumins + globulins & prolamins & glutelins \\
\hline control (60-70\% SWC) & 43149 & 22831 & 25664 \\
water stress (30-35\% SWC) & 44416 & 23659 & 22361 \\
\hline
\end{tabular}

Measurements of the biometric traits of the water-stressed oats cv. Flämingsstern, conducted during this study, also showed that water stress had a significant impact on the reduction in the number of panicles per plant (Table 1). A declining trend was found also for TGW and number of grains per panicle, although these differences were not statistically proved (Table 1). The study of Michalski et al. (1999) on the effect of rainfall amounts and distribution on oat yields, carried out under field conditions during the period from April to June, showed that this species produced the highest yield when a cool May was followed by a wet June with rainfall levels of 80-100 mm. R u d n i c k i (1995) demonstrated a beneficial influence of the following rainfall and thermal conditions on the productivity of oats: "a warm and wet April, not very cool May with moderate rainfall levels, a warm June with above-average rainfall, and an averagely warm or warm July with high amounts of rainfall". In the case of oats, average rainfall total close to the long-term average $(190 \mathrm{~mm}$ from April to July) has the most beneficial effect on their productivity when rainfall distribution in particular months is as follows: $10 \%$ in April, about $21 \%$ in May, $19 \%$ in June, and $50 \%$ in July. Similar results obtained by R u d n i c k i (1995) show a clear increase in oat yields with increasing rainfall. The study of K o z i a r a (2004) proved that there was a significant increase in yield under the influence of sprinkler irrigation, but this increase varied, ranging from $9.5 \%$ to $79.6 \%$. The number of productive panicles and 1000 grain weight also increased. However, the abovementioned author did not demonstrate the impact of sprinkler irrigation on the number of grains per panicle. In turn, M i c hals ki et al. (2003) found that a drought during the growing period (in the years 2000 and 2001) had an adverse effect on thousand grain weight.

Water stress resulted in reduced rates of the investigated gas exchange parameters in oats both in the first and second year of the study (Table 2 and 3). Significant differences were found in the rates of photosynthesis and transpiration at the plant growth stages in question. O ls ze w s ki et al. (2007, 2009A) as well as P s z c z ół k o w s k a et al. (2003) also showed that water deficit in the soil resulted in a reduction of the gas exchange rates, primarily the rate of photosynthesis. The results of the present study showed that the values obtained for the rates of photosynthesis, stomatal conductance and transpiration under conditions of optimal soil moisture content did not significantly differ from those obtained for oats in the study of P i o t r o w s k a et al. (2003).

In the first year of the study, it was demonstrated that oat kernels from the control treatment were colonized by fungi to a greater degree than kernels that had grown under water stress conditions (Table 4). In 2004 Cladosporium cladosporioides was the dominant species in both treatment combinations. Under the control conditions, 15 isolates of $F$. poae were identified, whereas under water stress conditions 6 isolates belonging to this species (Table 4). A reverse correlation was found in the second year of the study (2005), since more fungal isolates were obtained from waterstressed kernels (Table 5). Cladosporium cladosporioides was also the most frequently isolated species. Among the investigated fungi of the genus Fusarium, similarly as in 2004, the presence of $F$. poae was only found -1 isolate in the control treatment and 3 isolates under water deficit conditions (Table 5). However, it should be stated that in 2005 the number of fungal cultures isolated from the oat grain was relatively low, and Fusarium poae was represented by single isolates.

Cladosporium cladosporioides was the dominant species in both years of the study. But the study conducted by Kowalczyk and Maciorow s k (2006) showed that the following fungi occurred most frequently on the grain of naked oats grown under field conditions: Alternaria alternata, Epicoccum purpurascens, Fusarium poae, Penicillium spp., and non-sporulating colonies. B u r g i e $\mathrm{f}$ and $\mathrm{P}$ i s u $\mathrm{l}$ e w s k a (2003) also confirmed that Alternaria alternata, Epicoccum purpurascens, Penicillium spp., and Fusarium culmorum were the dominant species. However, $\mathrm{M}$ i c h a lski and Horoszkiew icz-J anka (2003) indicated Alternaria tenuis as the dominant species both on the husked and naked form.

It was found in the present study that the toxinproducing fungi of the genus Fusarium were represented only by one species, Fusarium poae. The research 
on fungal colonization of grain (from field crops) of 23 breeding oat stocks, conducted by Kow a lc z y k and M a c i or o w s k i (2006), also showed the dominance of Fusarium poae. On the other hand, B u r $\mathrm{g}$ i e 1 and Pisulewska (2003) indicated the occurrence of Fusarium culmorum in great numbers. In the opinion of Mielniczuk (2001) and Kiecana et al. (2005), Fusarium avenaceum and Fusarium poae belong to the fungi of the genus Fusarium which occur most frequently on oat grain. K i e c a n a et al. (2005) also showed that Fusarium poae played a major role in inducing fusariosis of oat panicles. P a c k a (2005) demonstrated that the percentage of Fusarium fungi in the grain of naked oats was $16.2 \%$ in the control treatment (non-inoculated), and the following were found in greatest numbers: Fusarium avenaceum, Fusarium culmorum, and Fusarium poae. In addition to the abovementioned species, this author also found the presence of Fusarium poae in the oat grain in the treatments in which panicles had been inoculated with the species Fusarium culmorum and Fusarium avenaceum.

Qualitative analysis of proteins in the oat grain showed an increase in albumin, globulin and prolamin fractions, whereas in the case of glutelin fractions a reverse correlation was found (Table 6). According to O 1 s z e w s ki et al. (2009B), during a drought period, both throughout the entire growing season and in the period from flowering to full maturity, the grain of oats cv. Flämingsstern contained more prolamins as well as albumins and globulins than the grain from the control conditions. The study of K o n o p k a et al. (2007) also showed changes in protein fractions in the grain of water-stressed cereals.

\section{CONCLUSIONS}

1. Water deficit in the period from panicle half emerged to the milk stage of grain development resulted in a decrease in grain weight per plant.

2. Under conditions of reduced soil moisture content, a decrease in the gas exchange rates was found, mainly in the rates of photosynthesis and transpiration.

3. Cladosorium cladosporioides was the dominant species on kernels in both experimental treatment options and in both years of the study; moreover, the presence of a toxin-producing species, Fusarium poae, was found in the oat grain.

4. Under soil water deficit conditions, the oat grain was characterized by higher contents of prolamins, albumins, and globulins.

This study was supported by the Ministry of Education and Science in Poland, grant no. PBZ-KBN09/P06/2003.

\section{LITERATURE}

Bartnikowska E., Lange E., Rakowska M., 2000A. Oat grain - not enough appreciated source of nutrients and biologically active substances. Part I. Proteins and lipids. Biul. IHAR, 215: 223-237.

Bartnikowska E., Lange E., Rakowska M., 2000B. Oat grain - not enough appreciated source of nutrients and biologically active substances. Part II. Polysaccharides and dietary fiber, mineral substances and vitamins. Biul. IHAR, 215: 209-222.

B u rg i eł Z., P is u lew s k a E., 2003. Naked oats seed-borne fungi. Biul. IHAR, 229: 205-210.

E11 is M. B., 1971. Dematiaceous Hyphomycetes. Commonwealth Mycological Institute Kew, Surrey, England.

Gą s i or ow ski H. (red.), 1995. Owies. Chemia i technologia. Państwowe Wydawnictwo Rolnicze i Leśne, Poznań (in Polish).

Gąsiorowski H., Kawka A., 1995. Wykorzystanie owsa. [In:] H. Gąsiorowski (ed), Owies. Chemia i technologia.Państwowe Wydawnictwo Rolnicze i Leśne, Poznań: 159-174 (in Polish).

Gilman J. C., 1957. A manual of soil fungi. The Iowa State University, Ames USA.

Grzesiuk S., Koczowska I., Górecki R. J., 1999. Fizjologiczne podstawy odporności roślin na choroby. I The physiological basis for plant resistance to diseases. Wyd. II. ART Olsztyn (in Polish).

Kiecana I., Mielniczuk E., Perkowski J., Goliński P., 2005. Infection of panicles with Fusarium poae (Peck) Wollenw. and mycotoxin content in oat grain. Acta Agrobot. 59 (2): 91-102.

Konopka I., Tańska M., Pszczółkowska A., Fordoński G., Kozirok W., Olszewski J., 2007. The effect of water stress on wheat kernel size, color and protein composition. Pol. J. Natur. Sci. 22 (2): 157-171.

Kowa lc zyk S., M a ci or ow sk i R., 2006. Fungi colonizing seed of dwarf and semi-dwarf naked oat. Biul. IHAR, 239: $165-171$.

Ko zi a r a W., 2004. Response of three oats cultivars to sprinkler irrigation and nitrogen fertilization. Biul. IHAR, 231: 397-403.

Kwaśna H., Chełkowski J., Zajkowski P., 1991. Grzyby. Tom XXII. (Flora Polska). PAN Instytut Botaniki Warszawa - Kraków (in Polish).

Michalski T., Horoszkiewicz-Janka J., 2003. Fungi infesting grain of naked oats and husked oats depending on system of plant protection. Biul. IHAR, 229: 211-219.

Michalski T., Idziak R., Menzel L., 1999. Effect of weather conditions on oats yields. Żywność. Nauka. Technologia. Jakość. Supl., Kraków, 1 (18): 46-52.

Mielniczuk E., 2001. The occurrence of Fusarium on panicles of oats (Avena sativa L.). J. Plant Protection Research, 41 (2): 173-180. 
Nicholson P., Chandler E., Draeger R. C., Gosman N. E., Simp son D. R., Thom sett M., Wilson A. H., 2003. Molecular tools to study epidemiology and toxicology of Fusarium head blight of cereals. Eur. J. Plant Pathol. 109: 691-703.

Nichols on P., Simpson D. R., Wilson A. H., Chandler E., Thomset T. M., 2004. Detection and differentiation of trichothecene and enniatin - producing Fusarium species on small grain cereals. Eur. J. Plant Pathol. 110: 503-514.

Olszewski J., Pszczółkowska A., Kulik T., Fordoński G., Płodzień K., Okorski A., Wa sielewska J., 2007. Effect of water deficit on gas exchange parameters, productivity and grain health of winter whet cultivars. Acta Sci. Pol. Ser. Agri. 6 (4): 33-42.

Olszewski J., Pszczółkowska A., Makowska M., Kulik T., Okorski A., 2009A. Effect of water deficit on gas exchange parameters, productivity and grain wholesomeness of spring wheat. Pol. J. Natur. Sc. 24 (2): 85-92.

Olszewski J., Podolska G., Pszczółkowska A., 2009B. Stres biotyczny i abiotyczny oraz czynniki agrotechniczne a zawartość w nasionach ważnych roślin uprawnych białek powodujących nietolerancje pokarmowe. [In:] J. Dziuba, Ł. Fornal (eds), Biologicznie aktywne peptydy i białka żywności. Wydawnictwo Naukowo-Techniczne, Warszawa: 388-456 (in Polish).

Packa D., 2005. Phytotoxic activity of necrotrophic pathogens from the genus Fusarium. Rozprawy i Monografie, Wyd. UWM, Olsztyn, 106: 100.

Panek K., 1992. Action and co-action of precipitations on the yielding of oat in different regions of the country. Biul. Inf. ART Olsztyn, 33: 95-104.

Piotrowska W., Pietkiewicz S., Wyszyński Z., Łoboda T., Gozdowski D., Kotlarska-Jaros E., St a n kow ski S., 2003. Gas exchange of oat depending on nitrogen fertilization. Biul. IHAR 229: 131137.

Podolaska G., Hołubowicz-Kliza G., 2006A. Response of winter wheat cv. Tonacja to drought stress. Rocz. AR Poznań (Rol.) 380 (66): 261-269.

Podolaska G., Hołubowicz-Kliza G., 2006B. Response of winter rye cv. Nawid to drought stress. Rocz. AR Poznań (Rol.) 380 (66): 271-277.

Pszczółkowska A., Olszewski J., Płodzień K., Ku lik T., Fordoński G., Żuk-Gołaszewska K., 2003. Effect of the water stress on productivity of selected genotypes of pea (Pisum sativum L.) and yellow lupin (Lupinus luteus L.). Electronic J. of Polish Agric. Univ. Ser. Agronomy, 6 (1): www.ejpau.media.pl/volume6/issue1/agronomy/art-02.html

Rudn icki F., 1995. Comparison of reaction of winter barley and the oats to rainfall and thermic conditions. Fragm. Agronom. 3 (47): 21-33.

Skrabka H., 1992. Roślina a środowisko. Wybrane działy z fizjologii roślin. Skrypt AR. Manuscript. Wrocław (in Polish).
Starck Z., Chołuj D., Niemyska B., 1995. Fizjologiczne reakcje roślin na niekorzystne czynniki środowiska. SGGW, Warszawa (in Polish).

Sułek A., Leszczyńska D., Cyfer R., 2005. Charakterystyka i technologia uprawy odmian owsa. / Characteristics and cultivation technology of oat varieties. $\mathrm{Pu}$ ławy-Radzików-Słupia Wielka. Wyd. IHAR Radzików (in Polish).

Wróbel E., Kijor a C., 2004. The effect of selected agronomic factors on yield and quality of naked oats grain. Pam. Puł. 135: 331-340.

Wieser H., Antes S., Seilmeier W., 1998. Quantitative determination of gluten protein types in wheat flour by reversed-phase high-performance liquid chromatography. Cerael Chem., 75 (5): 644-650.

\section{Produktywność i zdrowotność ziarna owsa oplewionego (Avena sativa L.) w warunkach zróżnicowanego uwilgotnienia gleby}

\section{Streszczenie}

Badano wpływ zróżnicowanego uwilgotnienia gleby $(60-70 \%$ ppw - kontrola; $30-35 \%$ ppw stres wodny) na plonowanie, wskaźniki wymiany gazowej, zdrowotność ziarna oraz frakcję białek ziarna owsa oplewionego. W badaniach wykazano, że niedobór wody przyczynił się do obniżenia masy ziaren z rośliny, zmniejszenia intensywności parametrów wymiany gazowej, a głównie fotosyntezy i transpiracji. W ziarniakach owsa w obu wariantach doświadczalnych i latach badań gatunkiem dominującym było Cladosporium cladosporioides. Stwierdzono również obecność Fusarium poae. W ziarnie owsa pochodzącym z roślin uprawianych w warunkach niedoboru wody w podłożu stwierdzono większą zawartość frakcji prolamin oraz albumin i globulin. 
